\title{
Precipitate Evolution in 22Cr25NiWCuCo(Nb) Austenitic Heat-Resistant Stainless Steel during Heat Treatment at $1200{ }^{\circ} \mathrm{C}$
}

\author{
Sheng-Min Yang ${ }^{1, *}$, Jing-Lin $\mathrm{Wu}^{1}{ }^{1}$, Yeong-Tsuen Pan $^{2}$ and Dong-Yih Lin ${ }^{1, *}$ \\ 1 Department of Chemical and Materials Engineering, National University of Kaohsiung, \\ Kaohsiung City 811, Taiwan; qwe7711989@gmail.com \\ 2 Gerneral Manager Office, ThinTech Materials Technology Co., LTD., Kaohsiung City 811, Taiwan; \\ ytpan2005@gmail.com \\ * Correspondence: min6624@ms27.hinet.net (S.-M.Y.); dylin@nuk.edu.tw (D.-Y.L.); \\ Tel.: +886-7-5919739 (D.-Y.L.)
}

Citation: Yang, S.-M.; Wu, J.-L.; Pan, Y.-T.; Lin, D.-Y. Precipitate Evolution in $22 \mathrm{Cr} 25 \mathrm{NiWCuCo}(\mathrm{Nb})$ Austenitic Heat-Resistant Stainless Steel during Heat Treatment at $1200^{\circ} \mathrm{C}$. Materials 2021, 14, 1104. https://doi.org/ 10.3390/ma14051104

Academic Editor:

Panagiotis Tsakiropoulos

Received: 14 January 2021

Accepted: 22 February 2021

Published: 26 February 2021

Publisher's Note: MDPI stays neutral with regard to jurisdictional claims in published maps and institutional affiliations.

Copyright: (c) 2021 by the authors. Licensee MDPI, Basel, Switzerland. This article is an open access article distributed under the terms and conditions of the Creative Commons Attribution (CC BY) license (https:// creativecommons.org/licenses/by/ $4.0 /)$.

\begin{abstract}
In this study, $22 \mathrm{Cr} 25 \mathrm{NiWCuCo}(\mathrm{Nb})$ heat-resistant steel specimens with high $\mathrm{Cr}$ and $\mathrm{Ni}$ contents were adopted to investigate the effect of $\mathrm{Nb}$ content on thermal and precipitation behavior. Differential scanning calorimetry profiles revealed that the melting point of the $22 \mathrm{Cr} 25 \mathrm{NiWCuCo}(\mathrm{Nb})$ steel specimens decreased slightly with the $\mathrm{Nb}$ content. After heat treatment at $1200^{\circ} \mathrm{C}$ for $2 \mathrm{~h}$, the precipitates dissolved in a $\mathrm{Nb}$-free steel matrix. In addition, the $\mathrm{Z}$ phase $(\mathrm{CrNb}(\mathrm{C}, \mathrm{N}))$ and $\mathrm{MX}$ $(\mathrm{Nb}(\mathrm{C}, \mathrm{N}),(\mathrm{Cr}, \mathrm{Fe})(\mathrm{C}, \mathrm{N})$, and $\mathrm{NbC})$ could be observed in the $\mathrm{Nb}$-containing steel specimens. The amount and volume fraction of the precipitates increased with the $\mathrm{Nb}$ content, and the precipitates were distributed heterogeneously along the grain boundary and inside the grain. Even when the heat treatment duration was extended to $6 \mathrm{~h}$, the austenitic grain size and precipitates became coarser; the volume fraction of the precipitates also increased at $1200^{\circ} \mathrm{C}$. The $\mathrm{Z}$ phase, rather than the MX phase, became the dominant precipitates at this temperature.
\end{abstract}

Keywords: heat-resistant steel; MX; precipitation; Z phase; Nb-doping

\section{Introduction}

Austenitic heat-resistant steel exhibits a high creep resistance [1,2] and high-temperature corrosion $[3,4]$. Solution strengthening and precipitation strengthening constitute the primary techniques for strengthening the characteristics of such steel or alloys. These techniques entail the addition of alloy elements to impart $\mathrm{M}_{23} \mathrm{C}_{6}, \mathrm{MX}$, Laves, and $\mathrm{Z}$ phases, as well as $\mathrm{Cu}$-rich precipitates [5-8]. Sanicro 25 steel is considered an excellent engineering material that can be used in the high-pressure and high-temperature environments of high-efficiency power stations [9]. Sanicro 25 steel is composed of approximately $22 \% \mathrm{Cr}, 25 \% \mathrm{Ni}$, and many alloys $(\mathrm{W}, \mathrm{Nb}, \mathrm{Co}, \mathrm{Mn}, \mathrm{Si}, \mathrm{Cu}$, and $0.2 \%$ excess $\mathrm{Nb}$ ) that contribute to its hot corrosion resistance and stabilize and strengthen the austenite matrix [10-12]. Studies have reported that Sanicro 25 steel possesses high strength properties and high creep resistance because of the stable microstructure of the Z, Laves, and MX phases at high temperatures [13-15]. Zurek et al. presented a detailed report on the formation of precipitates of Sanicro 25 steel, including those in the form of a $\mathrm{Z}-(\mathrm{Nb}, \mathrm{Cr}) \mathrm{N}$ phase, chromium nitride $\left(\mathrm{Cr}_{2} \mathrm{~N}\right)$, a tungstenrich phase, and a $\mu$ phase $\left(\mathrm{F}_{\mathrm{e} 7} \mathrm{~W}_{6}\right)$, at temperatures between 600 and $750{ }^{\circ} \mathrm{C}$ for up to $10,000 \mathrm{~h}$ [11]. Moreover, Li et al. studied the nucleation and growth of secondary $\mathrm{NbCrN}$ in $25 \mathrm{Cr}-20 \mathrm{Ni}-\mathrm{Nb}-\mathrm{N}$ steel during long-term aging at $700{ }^{\circ} \mathrm{C}$, revealing that $\mathrm{NbN}$ can provide a favorable site for the nucleation of $\mathrm{NbCrN}$ and that $\mathrm{NbN}$ can dissolve to supply $\mathrm{Nb}$ and $\mathrm{N}$ for $\mathrm{NbCrN}$ growth [16-19]. However, the phase transformation mechanism with respect to the applied alloys, temperature, and time is unclear. Understanding the phase components from the solidus temperature to $120{ }^{\circ} \mathrm{C}$ is beneficial for controlling the phase transformations during thermal processes. 
Z-phase and MX precipitates are crucial in austenitic heat-resistant steel. Most studies have focused on precipitation behavior between 600 and $750{ }^{\circ} \mathrm{C}$ in long-term aging. Moreover, $\mathrm{Nb}$ is an essential alloy involved in precipitate nucleation. Controlling the heterogeneous primary precipitates (precipitation temperature $>1200^{\circ} \mathrm{C}$ ) significantly influences the nucleation and growth of secondary precipitates during warm working. Therefore, in the present study, $22 \mathrm{Cr} 25 \mathrm{NiWCoCu}$ steel specimens were doped with different contents of $\mathrm{Nb}$ and subjected to heat treatment at $1200^{\circ} \mathrm{C}$ for $2-6 \mathrm{~h}$; the resulting microstructures, precipitates, and phase compositions were investigated. Understanding the phase constitution at the high temperature of $1200{ }^{\circ} \mathrm{C}$ is crucial because high-temperature phases influence precipitation behavior below the solution temperature. The distribution, particle size, and volume fraction of the precipitates were also evaluated, and the thermal stabilization of the doped $22 \mathrm{Cr} 25 \mathrm{NiWCuCo}(\mathrm{Nb})$ steel specimens was investigated through thermal analysis to determine the relationship between $\mathrm{Nb}$ doping and the precipitates.

\section{Materials and Methods}

Heat-resistant $22 \mathrm{Cr} 25 \mathrm{NiWCoCu}$ steel was doped with different contents of $\mathrm{Nb}(0,0.3$, 0.6 , and $0.9 \mathrm{wt} . \%)$; the steel was prepared through vacuum induction melting. The steel ingots were hot rolled at $1250^{\circ} \mathrm{C}$ and finished at an end-rolling temperature of $950{ }^{\circ} \mathrm{C}$, with a final reduction ratio of $80 \%$. Subsequently, the hot-rolled plates were subjected to heat treatment at $1200^{\circ} \mathrm{C}$ for $2 \mathrm{~h}$, followed by water cooling to maintain the high-temperature microstructure. The compositions of the $22 \mathrm{Cr} 25 \mathrm{NiWCuCo}(\mathrm{Nb})$ steel samples are presented in Table 1.

Table 1. Compositions of $22 \mathrm{Cr} 25 \mathrm{NiWCuCo}(\mathrm{Nb})$ steel specimens (wt.\%).

\begin{tabular}{cccccccccccccc}
\hline & $\mathbf{C r}$ & $\mathbf{N i}$ & $\mathbf{W}$ & $\mathbf{C u}$ & $\mathbf{C o}$ & $\mathbf{N}$ & $\mathbf{C}$ & $\mathbf{S i}$ & $\mathbf{M n}$ & $\mathbf{P}$ & $\mathbf{S}$ & $\mathbf{N b}$ & $\mathbf{F e}$ \\
\hline Nb-free & 22.20 & 24.40 & 3.39 & 2.90 & 1.47 & 0.23 & 0.07 & 0.19 & 0.49 & 0.009 & 0.005 & - & Bal. \\
$\mathrm{Nb}-0.3$ & 22.10 & 24.30 & 3.40 & 2.90 & 1.49 & 0.23 & 0.07 & 0.19 & 0.49 & 0.010 & 0.005 & 0.29 & Bal. \\
$\mathrm{Nb}-0.6$ & 21.90 & 24.20 & 3.36 & 2.90 & 1.45 & 0.23 & 0.07 & 0.20 & 0.49 & 0.010 & 0.005 & 0.58 & Bal. \\
$\mathrm{Nb}-0.9$ & 21.80 & 24.10 & 3.52 & 2.90 & 1.54 & 0.23 & 0.07 & 0.20 & 0.49 & 0.010 & 0.005 & 0.86 & Bal. \\
\hline
\end{tabular}

The $22 \mathrm{Cr} 25 \mathrm{NiWCuCo}(\mathrm{Nb})$ steel specimens were subjected to thermal analysis performed using a differential scanning calorimeter (Netzsch DSC 404) to obtain their differential scanning calorimetry (DSC) profiles. The analysis was executed at a maximum temperature of $1450{ }^{\circ} \mathrm{C}$ and heating rate of $5{ }^{\circ} \mathrm{C} / \mathrm{min}$ in an argon atmosphere with a flow rate of $100 \mathrm{~mL} / \mathrm{min}$. The microstructures and phases of the samples were examined using a field-emission electron probe microanalysis (FE-EPMA) system (JEOL JXA-8530F) equipped with instruments for energy-dispersive spectroscopy (EDX) and wavelengthdispersive spectrometry (WDS). The microstructure observation and WDS examination proceeded under an acceleration voltage of $15 \mathrm{keV}$. Field-emission transmission electron microscopy (FE-TEM) — executed using a JEM-2100F system (JEOL)—along with selected area electron diffraction (SAD) and EDX were adopted for fine precipitate identification. FE-TEM examination was carried out with an acceleration voltage of $200 \mathrm{keV}$. The TEM specimens were prepared using an advanced focused ion beam system (FEI Helios G3CX).

\section{Results}

Figure 1 presents the microstructures and precipitate morphologies of the $22 \mathrm{Cr} 25 \mathrm{Ni}$ $\mathrm{WCuCo}(\mathrm{Nb})$ steel specimens after heat treatment at $1200{ }^{\circ} \mathrm{C}$ for $2 \mathrm{~h}$. In the present study, precipitates in the $\mathrm{Nb}$-free steel dissolved in the austenitic matrix after $2 \mathrm{~h}$ of heat treatment, as presented in Figure 1a. The precipitates could be observed after heat treatment, and the number of precipitates increased with the $\mathrm{Nb}$ content. Accordingly, in the present study, the microstructures had large amounts of heterogeneously distributed precipitates after $2 \mathrm{~h}$ of heat treatment at $1200^{\circ} \mathrm{C}$. 


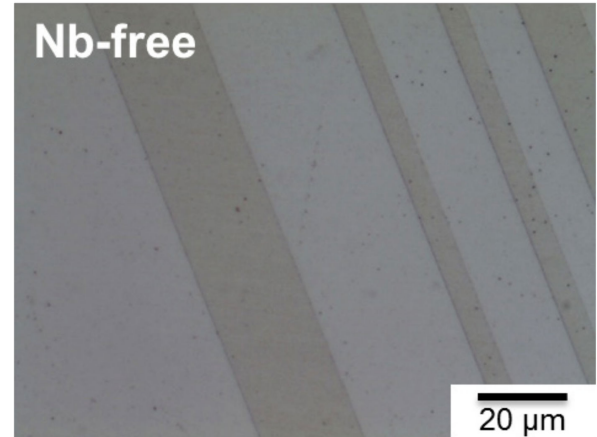

(a)

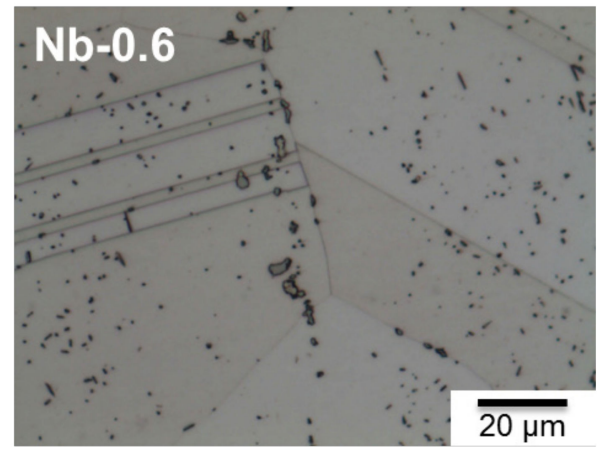

(c)

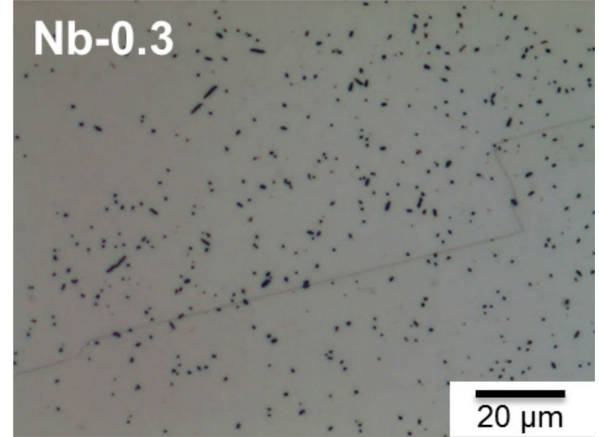

(b)

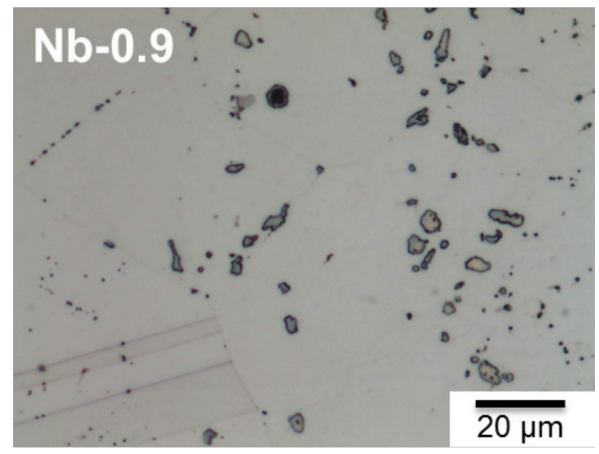

(d)

Figure 1. Optical microstructure and precipitate morphology of $22 \mathrm{Cr} 25 \mathrm{NiWCuCo}(\mathrm{Nb})$ steel specimens after heat treatment at $1200{ }^{\circ} \mathrm{C}$ for $2 \mathrm{~h}$ : (a) $\mathrm{Nb}$-free, (b) Nb-0.3, (c) Nb-0.6, and (d) $\mathrm{Nb}-0.9$ steel specimens.

As presented in Figure 2, the precipitates aggregated in the matrix and along the grain boundary. High-resolution TEM (HRTEM)/SAD was used to identify the precipitates. The $\mathrm{Nb}-0.3$ steel sample had a tetragonal $\mathrm{CrNbN}$ structure and an $\mathrm{MX}$ phase with an $\mathrm{NaCl}$-type structure (Figure 2a). The HRTEM/EDS investigation of chemical composition indicated that the MX precipitate possessed a large amount of $\mathrm{Nb}$ reacting with interstitial $\mathrm{C}$ and $\mathrm{N}$, as presented in Table 2 . The $\mathrm{Z}$ phase with a $(\mathrm{Cr}, \mathrm{Nb}) \mathrm{N}$ composition also contained interstitial $\mathrm{C}$ parts, and the atomic ratio of $\mathrm{C}$ to $\mathrm{N}$ was approximately 1-1.2. The dominant precipitate in the $\mathrm{Nb}-0.6$ steel specimen was $\mathrm{CrNbN}$ with a low $\mathrm{C}$ content (4.4-8.9 at.\%), and the MX precipitate was not observed in TEM analysis. In addition, the $Z$ phase and $\mathrm{MX}$ were the primary precipitates in the $\mathrm{Nb}-0.9$ steel specimen, similar to the $\mathrm{Nb}-0.3$ steel specimen. However, $\mathrm{Nb}$ and $\mathrm{C}$ appeared to be the predominant alloys in the $\mathrm{MX}$ in the $\mathrm{Nb}-$ 0.9 steel specimen, similar to the $\mathrm{NbC}$ compound, as indicated in Figure $2 \mathrm{c}$ and Table 2. In Figure 2c, points 11 and 13 correspond to the MX phase; point 11 represents $(\mathrm{Cr}, \mathrm{Fe})(\mathrm{C}, \mathrm{N})$, and point 13 represents $\mathrm{NbC}$. However, whether the diffusion phenomenon between $(\mathrm{Cr}$, $\mathrm{Fe})(\mathrm{C}, \mathrm{N})$ and $\mathrm{NbC}$ occurred with an increase in the isothermal time at a high temperature was unclear.

Figure 3 presents the DSC profiles of the $22 \mathrm{Cr} 25 \mathrm{NiWCuCo}(\mathrm{Nb})$ steel specimens obtained from the thermal analysis. For the $\mathrm{Nb}$-free steel specimen, the major endothermic peak started to form at $1388.5^{\circ} \mathrm{C}$-which is related to the melting point of steel, and it ended at the temperature of $1405.4{ }^{\circ} \mathrm{C}$. When the $\mathrm{Nb}$ content was increased to $0.9 \mathrm{wt} \%$, the temperature at which the major endothermic peak started to form decreased from 1388.5 to $1363.6{ }^{\circ} \mathrm{C}$, and the temperature at which it peaked decreased from 1405.4 to $1394.7^{\circ} \mathrm{C}$. These findings indicate that the melting point of the $22 \mathrm{Cr} 25 \mathrm{NiWCuCo}(\mathrm{Nb})$ steel specimens decreased slightly as the $\mathrm{Nb}$ content increased. Moreover, the $\mathrm{Nb}$-free steel specimen had an endothermic peak at $1175.2{ }^{\circ} \mathrm{C}$; by contrast, the $22 \mathrm{Cr} 25 \mathrm{NiWCuCo}(\mathrm{Nb})$ steel specimens exhibited exothermic peaks at temperatures ranging between 1191.7 and $1192.9^{\circ} \mathrm{C}$. To 
determine the mechanisms underlying the formation of these peaks, further examination was performed.

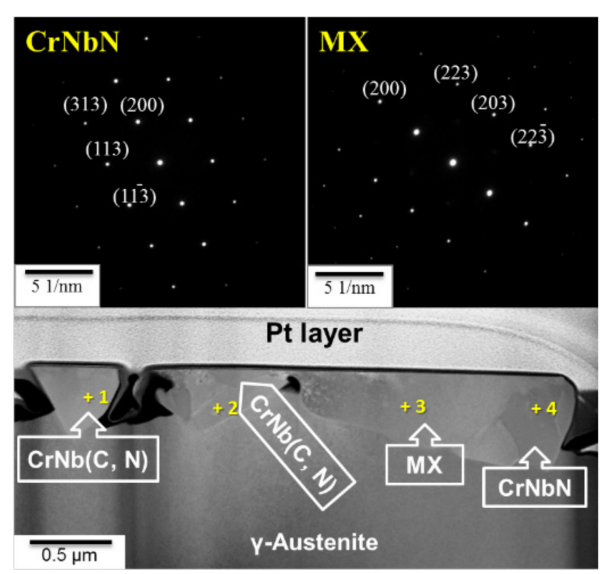

(a) $\mathrm{Nb}-0.3$

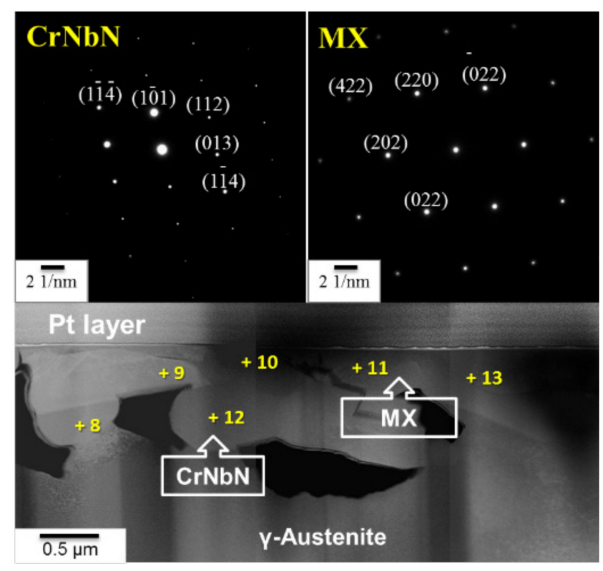

(c) $\mathrm{Nb}-0.9$

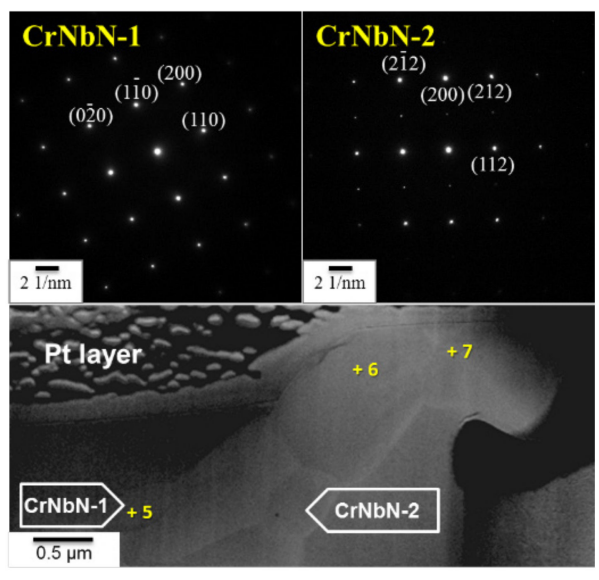

(b) $\mathrm{Nb}-0.6$

Figure 2. TEM-high-angle annular dark-field observation and analysis of $22 \mathrm{Cr} 25 \mathrm{NiWCuCo}(\mathrm{Nb})$ steel specimens after solution treatment at $1200{ }^{\circ} \mathrm{C}$ for $2 \mathrm{~h}$ : (a) $\mathrm{Nb}-0.3$, (b) $\mathrm{Nb}-0.6$, and (c) $\mathrm{Nb}-0.9$ steel specimens.

Table 2. High-resolution TEM (HRTEM)/EDX analysis of different phases in 22Cr25NiWCuCo(Nb) steel specimens after heat treatment at $1200^{\circ} \mathrm{C}$ for $2 \mathrm{~h}$ (for the marked points in Figure 2).

\begin{tabular}{|c|c|c|c|c|c|c|c|c|}
\hline & $\begin{array}{l}\mathrm{Cr} \\
\text { at.\% }\end{array}$ & $\begin{array}{c}\mathrm{Fe} \\
\text { at.\% }\end{array}$ & $\begin{array}{c}\mathrm{Nb} \\
\text { at.\% }\end{array}$ & $\begin{array}{c}\mathrm{W} \\
\text { at.\% }\end{array}$ & $\begin{array}{c}\mathrm{C} \\
\text { at.\% }\end{array}$ & $\begin{array}{c}\mathrm{N} \\
\text { at.\% }\end{array}$ & $\begin{array}{c}\text { Si } \\
\text { at. } \%\end{array}$ & Phase \\
\hline $1(\mathrm{Nb}-0.3)$ & $28.5 \pm 0.9$ & $5.5 \pm 0.3$ & $31.9 \pm 1.6$ & $2.5 \pm 0.8$ & $16.0 \pm 0.8$ & $15.6 \pm 0.5$ & - & $\mathrm{CrNb}(\mathrm{C}, \mathrm{N})$ \\
\hline $2(\mathrm{Nb}-0.3)$ & $26.2 \pm 0.9$ & $4.9 \pm 0.3$ & $29.1 \pm 1.6$ & $1.9 \pm 0.9$ & $20.8 \pm 0.9$ & $17.1 \pm 0.6$ & - & $\mathrm{CrNb}(\mathrm{C}, \mathrm{N})$ \\
\hline $3(\mathrm{Nb}-0.3)$ & $5.6 \pm 0.3$ & $3.4 \pm 0.2$ & $47.8 \pm 1.4$ & - & $27.0 \pm 1.0$ & $16.2 \pm 0.5$ & - & $\mathrm{MX}$ \\
\hline $4(\mathrm{Nb}-0.3)$ & $30.5 \pm 1.0$ & $4.0 \pm 0.3$ & $33.6 \pm 1.6$ & $1.3 \pm 0.9$ & - & $30.6 \pm 0.5$ & - & $\mathrm{CrNbN}$ \\
\hline $5(\mathrm{Nb}-0.6)$ & $29.8 \pm 1.0$ & $6.7 \pm 0.3$ & $30.2 \pm 1.5$ & $1.6 \pm 0.8$ & $8.9 \pm 0.8$ & $22.8 \pm 0.6$ & - & $\mathrm{CrNb}(\mathrm{C}, \mathrm{N})$ \\
\hline $6(\mathrm{Nb}-0.6)$ & $29.3 \pm 0.9$ & $3.9 \pm 0.2$ & $30.7 \pm 1.4$ & $1.7 \pm 0.6$ & $4.4 \pm 0.4$ & $30.0 \pm 0.5$ & - & $\mathrm{CrNb}(\mathrm{C}, \mathrm{N})$ \\
\hline $7(\mathrm{Nb}-0.6)$ & $27.1 \pm 0.8$ & $5.1 \pm 0.3$ & $34.1 \pm 1.6$ & $1.8 \pm 0.9$ & $4.9 \pm 0.6$ & $27.0 \pm 0.5$ & - & $\mathrm{CrNb}(\mathrm{C}, \mathrm{N})$ \\
\hline $8(\mathrm{Nb}-0.9)$ & $30.1 \pm 0.9$ & $5.3 \pm 0.3$ & $30.5 \pm 1.6$ & $1.3 \pm 0.9$ & $15.2 \pm 0.8$ & $17.6 \pm 0.6$ & - & $\mathrm{CrNb}(\mathrm{C}, \mathrm{N})$ \\
\hline $9(\mathrm{Nb}-0.9)$ & $24.9 \pm 0.8$ & $4.4 \pm 0.3$ & $30.3 \pm 1.5$ & $1.4 \pm 0.8$ & $30.1 \pm 1.0$ & $8.9 \pm 0.5$ & & $\mathrm{CrNb}(\mathrm{C}, \mathrm{N})$ \\
\hline $10(\mathrm{Nb}-0.9)$ & $28.4 \pm 0.9$ & $4.5 \pm 0.3$ & $31.1 \pm 1.6$ & $1.4 \pm 0.9$ & $25.6 \pm 0.9$ & $7.3 \pm 0.5$ & $1.7 \pm 0.6$ & $\mathrm{CrNb}(\mathrm{C}, \mathrm{N})$ \\
\hline $11(\mathrm{Nb}-0.9)$ & $36.1 \pm 1.2$ & $17.5 \pm 0.6$ & $3.0 \pm 0.6$ & $1.3 \pm 0.5$ & $22.7 \pm 1.0$ & $19.4 \pm 0.5$ & & $M X$ \\
\hline $12(\mathrm{Nb}-0.9)$ & $33.3 \pm 1.1$ & $5.3 \pm 0.2$ & $29.4 \pm 1.4$ & $1.9 \pm 1.0$ & $12.6 \pm 0.7$ & $16.3 \pm 0.6$ & $1.2 \pm 0.6$ & $\mathrm{CrNb}(\mathrm{C}, \mathrm{N})$ \\
\hline $13(\mathrm{Nb}-0.9)$ & $3.0 \pm 0.2$ & $1.6 \pm 0.3$ & $46.7 \pm 1.8$ & - & $41.9 \pm 1.2$ & $4.0 \pm 0.3$ & $2.8 \pm 0.8$ & $\mathrm{MX}$ \\
\hline
\end{tabular}




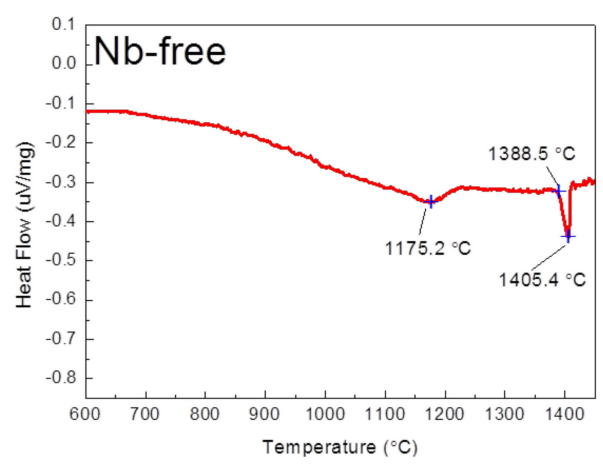

(a)

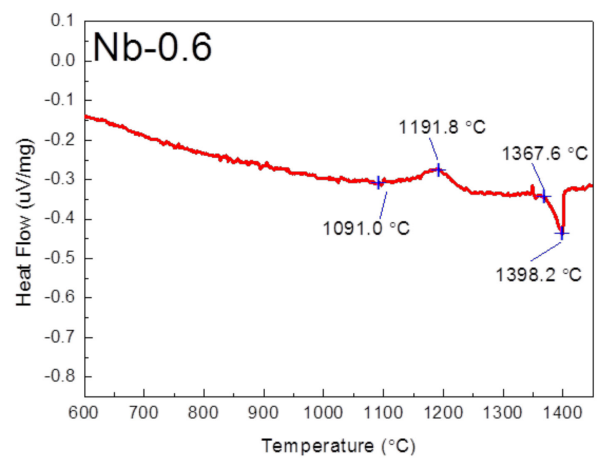

(c)

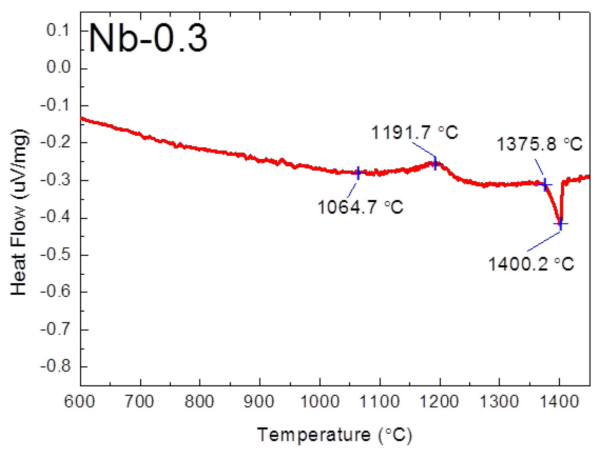

(b)

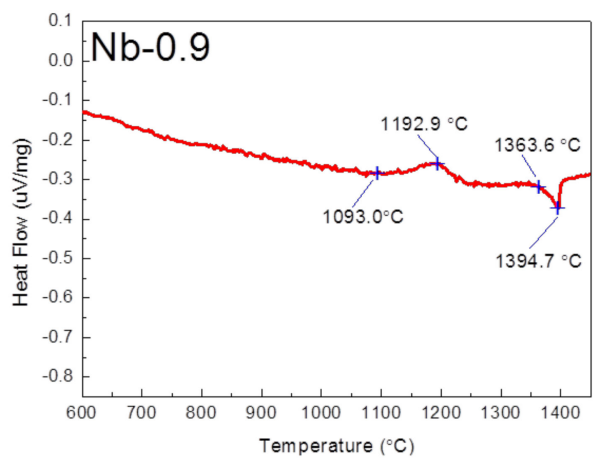

(d)

Figure 3. DSC profiles of the $22 \mathrm{Cr} 25 \mathrm{NiWCuCo}(\mathrm{Nb})$ steel specimens obtained from thermal analysis: $(\mathbf{a}) \mathrm{Nb}-\mathrm{free},(\mathbf{b}) \mathrm{Nb}-0.3$, (c) Nb-0.6, and (d) Nb-0.9 steel specimens.

The duration of the heat treatment was extended to $6 \mathrm{~h}$ to observe the stable phases at $1200{ }^{\circ} \mathrm{C}$ and confirm phase transformation processes in subsequent aging treatments. As indicated in Figure 4, the precipitates maintained stabilized random distributions in the $\mathrm{Nb}-0.3, \mathrm{Nb}-0.6$, and $\mathrm{Nb}-0.9$ steel specimens. After $6 \mathrm{~h}$ of heat treatment, the precipitates assembled into aggregation structures in the matrix and along the grain boundary; this behavior was the same as that observed in the $2 \mathrm{~h}$ heat treatment. Table 3 presents the FE-EPMA/WDX analysis results for the various phases in the $22 \mathrm{Cr} 25 \mathrm{NiWCuCo}(\mathrm{Nb})$ steel specimens after heat treatment at $1200{ }^{\circ} \mathrm{C}$ for $6 \mathrm{~h}$. As the precipitates in the $\mathrm{Nb}-0.3$ steel specimen had a small particle size $(<1 \mu \mathrm{m})$, distinguishing between the $\mathrm{Z}$ phase and MX was difficult. Although the probe size of the FE-EPMA/WDX system was approximately $0.5 \mu \mathrm{m}$, the matrix influenced the identification of the precipitate composition. Despite these difficulties, the analysis revealed that the $C$ content was significantly lower than the nitrogen content in the $\mathrm{Nb}-0.3$ steel specimen. Similar composition results were obtained for the $\mathrm{Nb}-0.6$ and $\mathrm{Nb}-0.9$ steel samples. Furthermore, the WDS analysis results revealed that the $\mathrm{Z}$ phase was the most dominant phase during treatment at $1200{ }^{\circ} \mathrm{C}$. This finding suggests that the $\mathrm{NbC}$ carbide was completely dissolved into the matrix and that $\mathrm{NbN}$ gradually transformed into $\mathrm{CrNbN}$ during heat treatment at $1200{ }^{\circ} \mathrm{C}$.

After $6 \mathrm{~h}$ of heat treatment at $1200{ }^{\circ} \mathrm{C}$, the austenitic grains and precipitates became coarser. The average size of the austenitic grains decreased as the $\mathrm{Nb}$ content increased in both the 2 and $6 \mathrm{~h}$ heat treatment processes executed at $1200{ }^{\circ} \mathrm{C}$. Compared with the measurements obtained after the $2 \mathrm{~h}$ heat treatment, the average grain size decreased by approximately $5.9 \%$ in the $\mathrm{Nb}$-free steel sample and increased by approximately $10-23 \%$ in the $\mathrm{Nb}$-doped steel samples after the $6 \mathrm{~h}$ heat treatment (Figure 5). As displayed in Figure 6, the average particle size of the precipitates increased from $0.7 \pm 0.37$ to $1.28 \pm 1.03 \mu \mathrm{m}$ as the $\mathrm{Nb}$ content increased. The $6 \mathrm{~h}$ heat treatment contributed to the increased average particle size, and the precipitate growth rate was 22-30\%. As the precipitates assembled into aggregation structures, with each particle measuring hundreds of nanometers, quan- 
tifying the individual Z-phase and MX fractions was difficult. Therefore, the present precipitate quantification results are presented using the total $\mathrm{Z}$ and MX phases. An area of approximately $20 \mathrm{~mm}^{2}$ for each specimen was required for the quantitative calculation of the average austenitic grain size, particle size, and volume fraction of the precipitates.

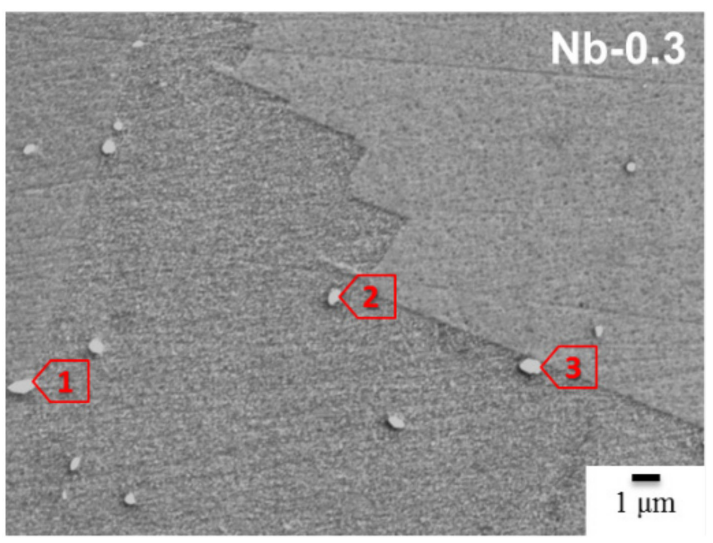

(a)

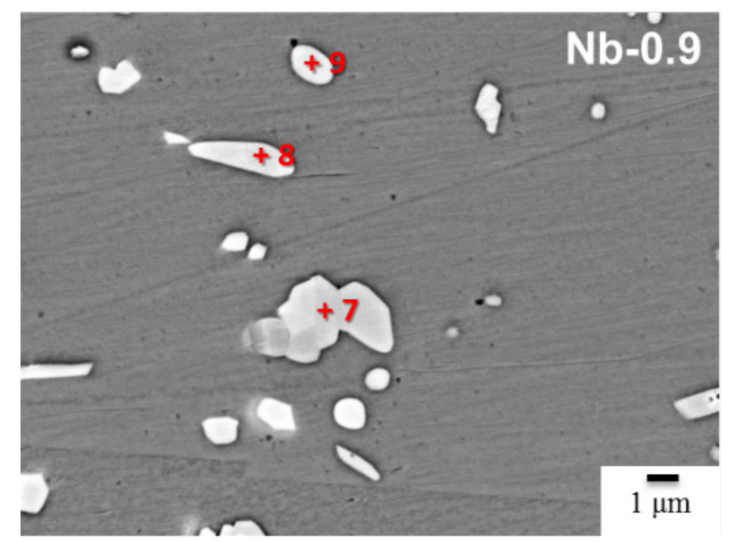

(c)

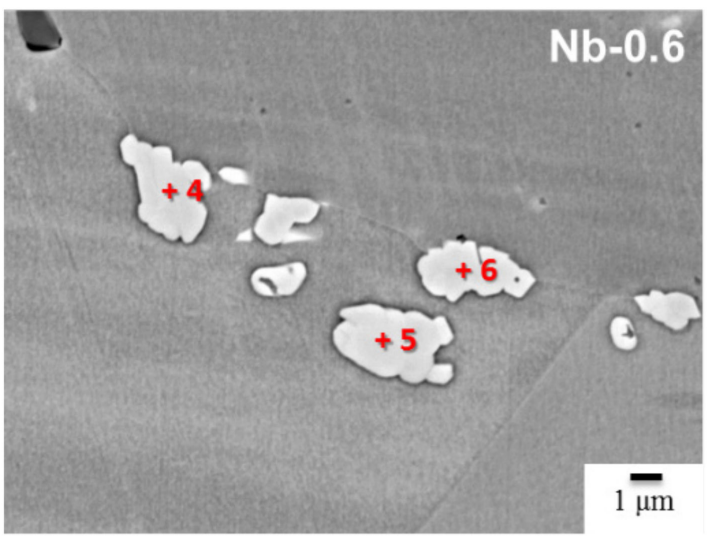

(b)

Figure 4. Microstructure and precipitate morphology of the $22 \mathrm{Cr} 25 \mathrm{NiWCuCo}(\mathrm{Nb})$ steel specimens after heat treatment at $1200{ }^{\circ} \mathrm{C}$ for $6 \mathrm{~h}:(\mathbf{a}) \mathrm{Nb}-0.3$, (b) Nb-0.6, and (c) Nb-0.9 steel specimens. (Marked points 1-9 is the chemical composition analysis which corresponding to Table 3.)

Table 3. EPMA/WDX analysis of different phases in the $22 \mathrm{Cr} 25 \mathrm{NiWCuCo}(\mathrm{Nb})$ steel specimens after heat treatment at $1200{ }^{\circ} \mathrm{C}$ for $6 \mathrm{~h}$ (for the marked points in Figure 4).

\begin{tabular}{lcccccccccc}
\hline & $\begin{array}{c}\mathbf{C r} \\
\text { at.\% }\end{array}$ & $\begin{array}{c}\mathbf{F e} \\
\text { at.\% }\end{array}$ & $\begin{array}{c}\mathbf{N b} \\
\text { at.\% }\end{array}$ & $\begin{array}{c}\mathbf{W} \\
\text { at.\% }\end{array}$ & $\begin{array}{c}\mathbf{C} \\
\text { at.\% }\end{array}$ & $\begin{array}{c}\mathbf{N} \\
\text { at.\% }\end{array}$ & $\begin{array}{c}\mathbf{C u} \\
\text { at.\% }\end{array}$ & $\begin{array}{c}\mathbf{N i} \\
\text { at.\% }\end{array}$ & $\begin{array}{c}\text { Co } \\
\text { at.\% }\end{array}$ & $\begin{array}{c}\text { Mn } \\
\text { at.\% }\end{array}$ \\
\hline $1(\mathrm{Nb}-0.3)$ & 29.3 & 27.6 & 14.9 & 1.3 & 3.3 & 7.5 & 1.2 & 13.7 & 0.8 & 0.4 \\
$2(\mathrm{Nb}-0.3)$ & 25.8 & 36.6 & 5.4 & 1.2 & 1.6 & 6.5 & 1.8 & 19.4 & 1.2 & 0.5 \\
$3(\mathrm{Nb}-0.3)$ & 23.8 & 34.9 & 5.6 & 1.0 & 2.1 & 11.1 & 1.6 & 18.2 & 1.2 & 0.5 \\
\hline $4(\mathrm{Nb}-0.6)$ & 29.1 & 4.5 & 29.5 & 1.3 & 4.2 & 30.3 & 0.1 & 0.8 & 0.1 & 0.1 \\
$5(\mathrm{Nb}-0.6)$ & 28.7 & 4.5 & 30.2 & 1.4 & 4.0 & 30.2 & - & 0.8 & 0.1 & 0.1 \\
$6(\mathrm{Nb}-0.6)$ & 28.8 & 4.3 & 32.0 & 1.5 & 4.5 & 28.1 & - & 0.6 & 0.1 & 0.1 \\
\hline $7(\mathrm{Nb}-0.9)$ & 27.3 & 4.5 & 28.6 & 1.3 & 2.9 & 34.2 & - & 0.9 & 0.2 & 0.1 \\
$8(\mathrm{Nb}-0.9)$ & 28.6 & 5.2 & 29.1 & 1.4 & 2.9 & 31.4 & - & 1.1 & 0.1 & 0.2 \\
$9(\mathrm{Nb}-0.9)$ & 27.0 & 12.4 & 22.9 & 1.3 & 2.9 & 27.8 & 0.4 & 4.9 & 0.3 & 0.1 \\
\hline
\end{tabular}




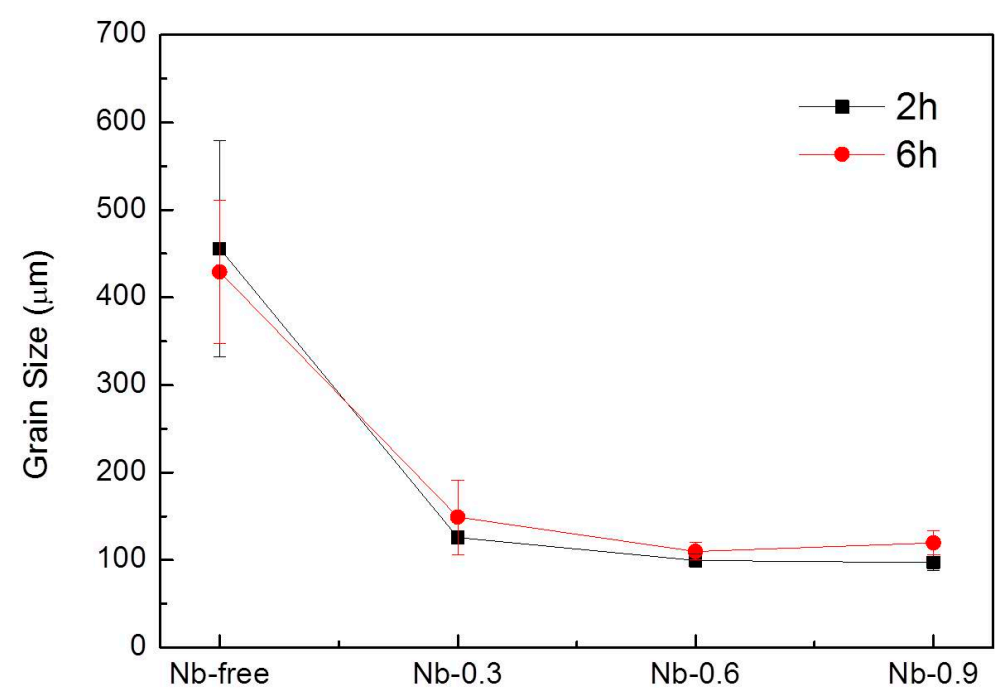

Figure 5. Average grain size as a function of $\mathrm{Nb}$ content in the $22 \mathrm{Cr} 25 \mathrm{NiWCuCo}(\mathrm{Nb})$ steel specimens after heat treatment at $1200^{\circ} \mathrm{C}$ for 2 and $6 \mathrm{~h}$.

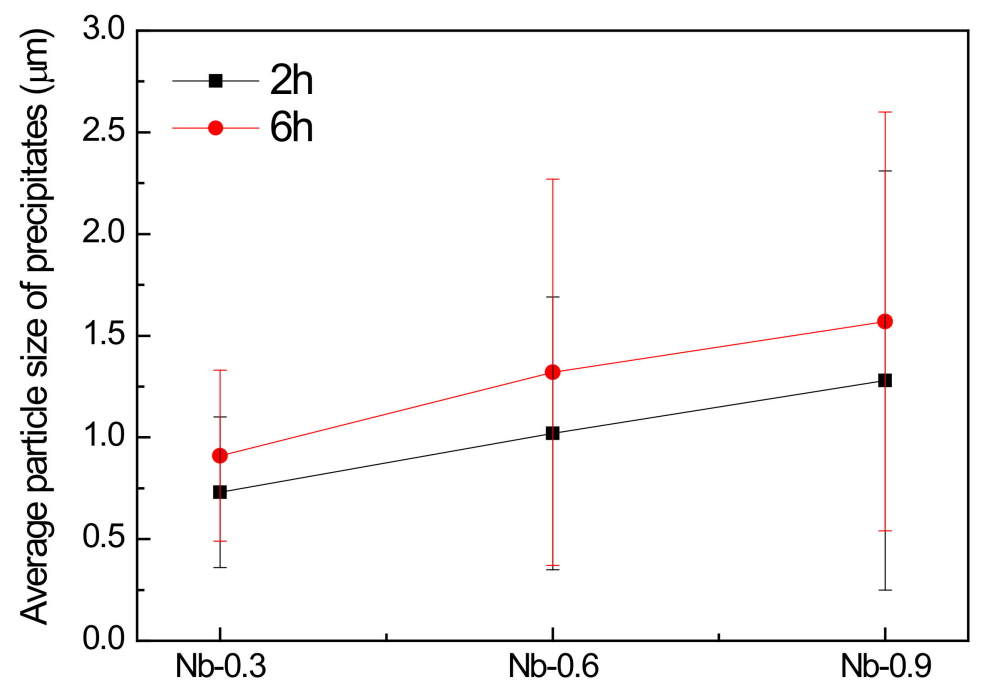

Figure 6. Average particle size of precipitates in the $22 \mathrm{Cr} 25 \mathrm{NiWCuCo}(\mathrm{Nb})$ steel specimens with different $\mathrm{Nb}$ contents after heat treatment at $1200{ }^{\circ} \mathrm{C}$ for 2 and $6 \mathrm{~h}$.

Figure 7 illustrates the relationship between $\mathrm{Nb}$ content and the volume fraction of precipitates after 2 and $6 \mathrm{~h}$ of heat treatment. During the $2 \mathrm{~h}$ heat treatment, the volume fraction of the precipitates was positively correlated with the growth rate and $\mathrm{Nb}$ content. The volume fraction was $1.3 \%$ in the $\mathrm{Nb}-0.3$ steel sample, $2.4 \%$ in the $\mathrm{Nb}-0.6$ steel sample, and $3.8 \%$ in the $\mathrm{Nb}-0.9$ steel specimen. The $6 \mathrm{~h}$ heat treatment contributed to the growth and coarsening of the MX precipitates, and the Z-phase precipitates increased in volume fraction. The volume fraction of the $\mathrm{Nb}-0.6$ steel specimen was close to that of the $\mathrm{Nb}-0.9$ steel specimen after the $6 \mathrm{~h}$ heat treatment. The histograms of precipitate size after heat treatment at $1200{ }^{\circ} \mathrm{C}$ for $2 \mathrm{~h}$ (Figure 8) indicate that the $\mathrm{Nb}-0.3$ steel specimen had numerous fine precipitates concentrated in the size range of $0.4-0.8 \mu \mathrm{m}$. This result differed from the uniform distributions of precipitates in the $\mathrm{Nb}-0.6$ and $\mathrm{Nb}-0.9$ steel specimens, signifying that high $\mathrm{Nb}$ content can promote the nucleation and growth of the MX and $\mathrm{Z}$ phases. The particle size distribution curve of the precipitates in the $\mathrm{Nb}-0.3$ steel specimen after $6 \mathrm{~h}$ of heat treatment indicates that numerous particles with a size of $0.5 \mu \mathrm{m}$ coarsened, resulting in a broad distribution curve (Figure 9a). This phenomenon of coarsening precipitates was also observed in the Nb-0.6 steel specimen (Figure $9 \mathrm{~b}$ ). However, the number of particles 
measuring $0.3-0.5 \mu \mathrm{m}$ in the $\mathrm{Nb}-0.9$ steel specimen abruptly increased after $6 \mathrm{~h}$ of heat treatment, meaning that numerous fine precipitates formed in this specimen (Figure 9c).

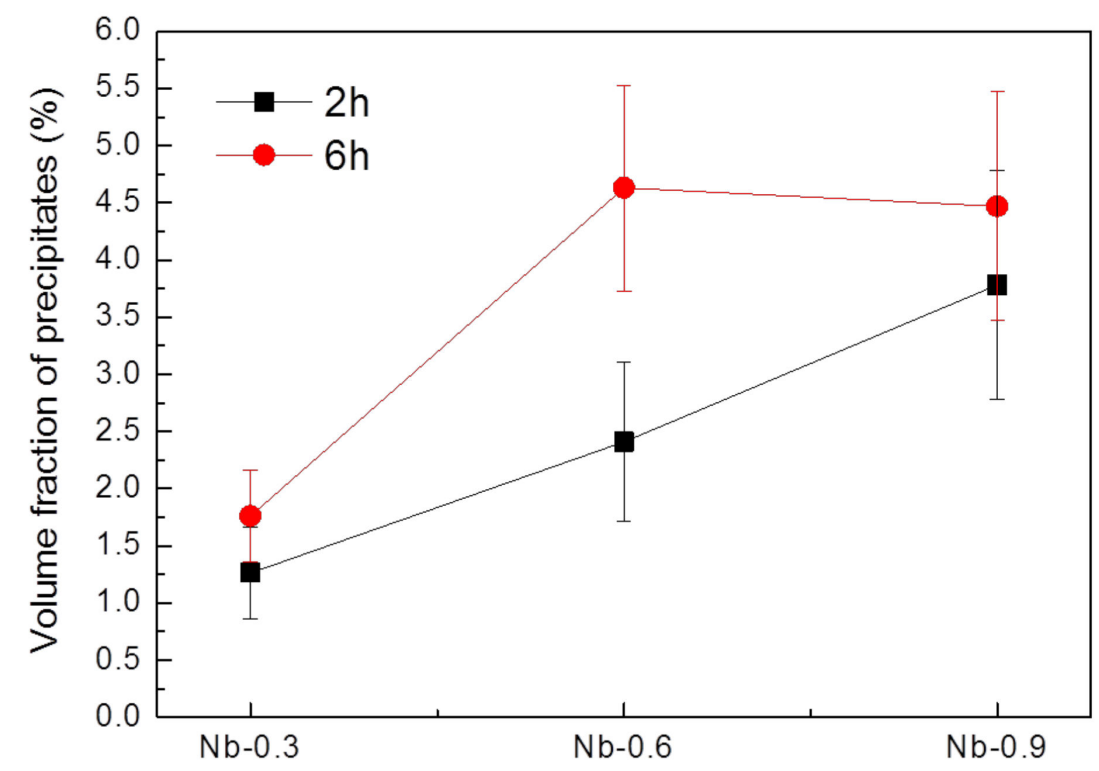

Figure 7. Volume fraction of precipitates in the $22 \mathrm{Cr} 25 \mathrm{NiWCuCo}(\mathrm{Nb})$ steel specimens with different $\mathrm{Nb}$ contents after heat treatment at $1200^{\circ} \mathrm{C}$ for 2 and $6 \mathrm{~h}$.

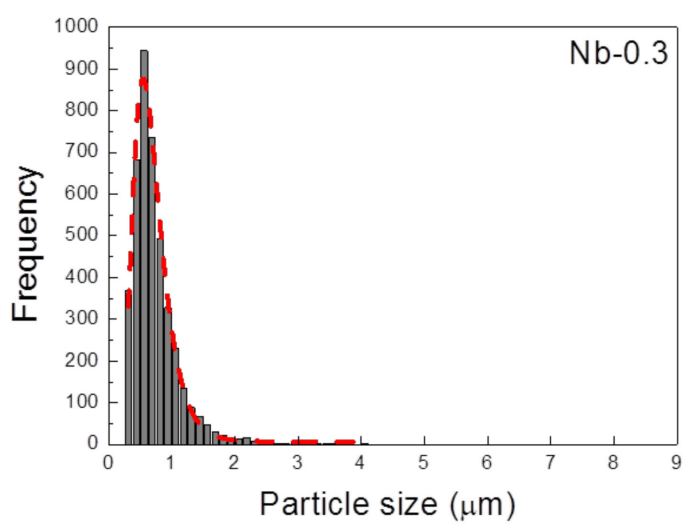

(a)

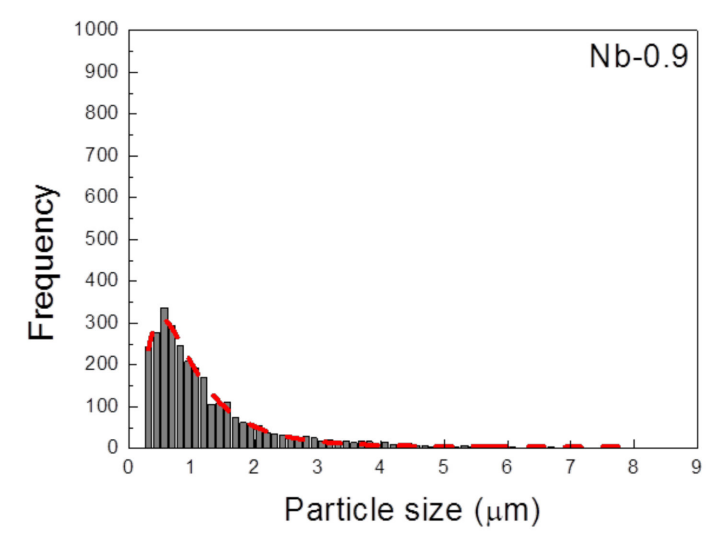

(c)

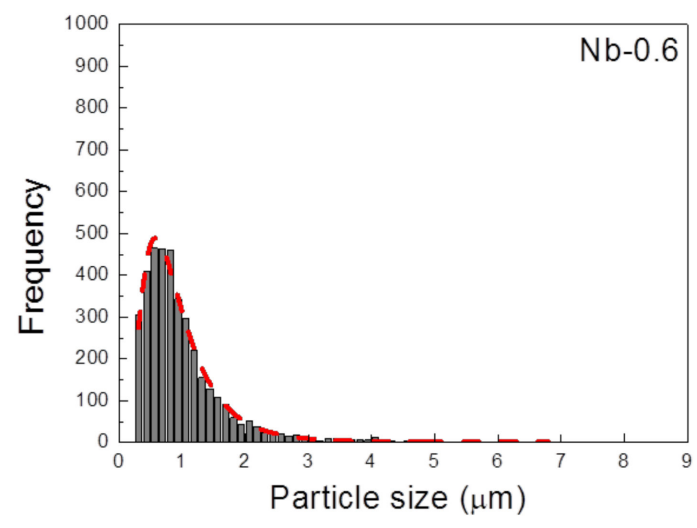

(b)

Figure 8. Histograms of precipitate size in the $22 \mathrm{Cr} 25 \mathrm{NiWCuCo}(\mathrm{Nb})$ steel specimens with different $\mathrm{Nb}$ contents after heat treatment at $1200{ }^{\circ} \mathrm{C}$ for $2 \mathrm{~h}$ : (a) $\mathrm{Nb}-0.3$, (b) $\mathrm{Nb}-0.6$, and (c) $\mathrm{Nb}-0.9$ steel specimens. 


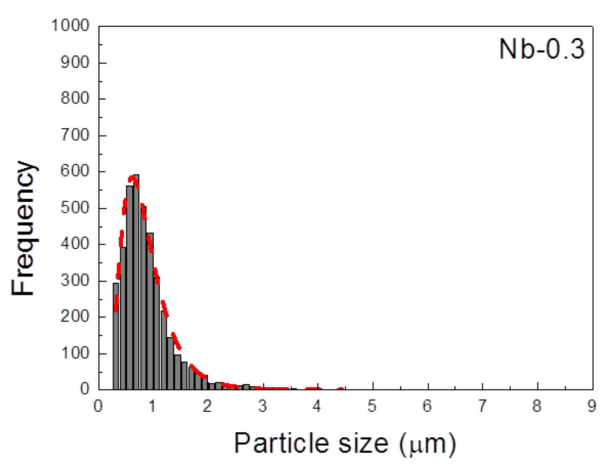

(a)

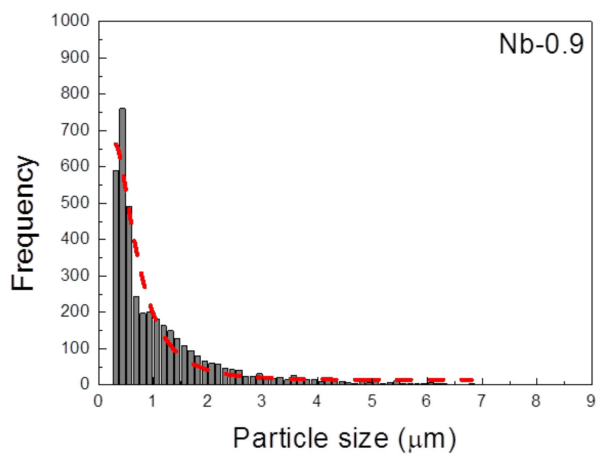

(c)

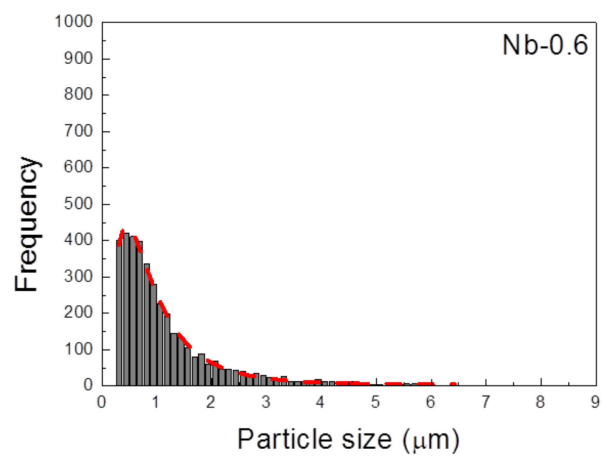

(b)

Figure 9. Histograms of precipitate size in $22 \mathrm{Cr} 25 \mathrm{NiWCuCo}(\mathrm{Nb})$ steel specimens with different $\mathrm{Nb}$ contents after heat treatment at $1200{ }^{\circ} \mathrm{C}$ for $6 \mathrm{~h}$ : (a) $\mathrm{Nb}-0.3$, (b) $\mathrm{Nb}-0.6$, and (c) $\mathrm{Nb}-0.9$ steel specimens.

\section{Discussion}

The precipitates morphology of the $22 \mathrm{Cr} 25 \mathrm{NiWCuCo}(\mathrm{Nb})$ steel specimens also appeared to become coarser as the $\mathrm{Nb}$ content increased, as shown in Figure 1. In the steel specimens containing $\mathrm{Nb}$, a sufficient amount of free $\mathrm{Nb}$ had a high affinity to react with $\mathrm{C}$ or $\mathrm{N}$ that was available in the solid solution, resulting in precipitates such as Z-phase, $\mathrm{MX}$ carbonitride, $\mathrm{M}_{23} \mathrm{C}_{6}$, and $\mathrm{Cu}$-rich precipitates [20-22]. Many studies have demonstrated that the grain boundary has higher interfacial energy than the grain does and provides a faster diffusion path for alloying $[8,23,24]$. Therefore, the nucleation and growth of different types of precipitates have been observed along the grain boundary and even inside the grains. From the chemical composition of precipitates that could be observed, the $\mathrm{Z}$ phase with a $(\mathrm{Cr}, \mathrm{Nb}) \mathrm{N}$ composition also contained interstitial $\mathrm{C}$ parts in $\mathrm{Nb}-0.3$ and $\mathrm{Nb}-0.6$ steels, where Raghavan et al. has also discussed the dissolution of carbon in $\mathrm{CrNbN}$ to form $\mathrm{CrNb}(\mathrm{C}, \mathrm{N})$ [25]. However, the $\mathrm{MX}$ became one of the predominant phases in the $\mathrm{Nb}-0.9$ steel specimen because $\mathrm{Nb}-0.9$ steel contained the higher $\mathrm{Nb}$ content. Sourmail argued that both the $\mathrm{Z}$ phase and $\mathrm{NbC}$ can be present because of the sufficient amount of $\mathrm{Nb}$ [19].

The DSC profiles of the $22 \mathrm{Cr} 25 \mathrm{NiWCuCo}(\mathrm{Nb})$ steel specimens obtained from the thermal analysis showed that the $\mathrm{Nb}$-free steel specimen had an endothermic peak at $1175.2^{\circ} \mathrm{C}$, and the $22 \mathrm{Cr} 25 \mathrm{NiWCuCo}(\mathrm{Nb})$ steel specimens exhibited exothermic peaks at temperatures ranging between 1191.7 and $1192.9^{\circ} \mathrm{C}$. Specifically, the fine precipitates formed in the $\mathrm{Nb}$-free steel specimen were examined using field-emission scanning electron microscopy and EDS, which revealed that oxides, carbides, and other impurities were the major compounds [19]. The precipitates and impurities dissolved in the matrix were presumed to have caused an exothermic reaction, which thus resulted in the endothermic peak observed for this specimen. Additionally, the endothermic reaction specimens underwent endothermic reactions at $1191.7-1192.9^{\circ} \mathrm{C}$, resulting in the formation of the MX and $\mathrm{CrNb}(\mathrm{C}) \mathrm{N}$ phases; these could have engendered the exothermic peaks observed for these specimens. According to the literature $[19,25,26]$, the $Z$ phase in austenitic stainless 
steel is stable at temperatures below $1300{ }^{\circ} \mathrm{C}$. The $\mathrm{Z}$ phase is also a predominant precipitate at a wide range of temperatures from 600 to $1200{ }^{\circ} \mathrm{C}$ [27]. As reported by Sourmail [19] and Heczko et al. [28], a high-temperature solid solution is an essential prerequisite for phase transformation among the $\mathrm{Z}$ phase, $\mathrm{Nb}(\mathrm{C}, \mathrm{N}), \mathrm{NbN}$, and $\mathrm{NbC}$. High-temperature treatment may thus have contributed to the nucleation and growth of the MX and Z-phase precipitates along the grain boundary and inner grain [29], as illustrated in Figures 1 and 2.

From the results of the average variation in austenitic grain size and average particle size of precipitates after 2 and $6 \mathrm{~h}$ of heat treatment at $1200^{\circ} \mathrm{C}$ (as shown in Figures 5 and 6), the $6 \mathrm{~h}$ heat treatment contributed to the increased average particle size and the precipitate growth rate. It indicates that precipitates hinder grain boundary movement, preventing grain growth and maintaining thermal stability [30]. These findings also show that the endothermic reaction between 1191.7 and $1192.9^{\circ} \mathrm{C}$ in the $22 \mathrm{Cr} 25 \mathrm{NiWCuCo}(\mathrm{Nb})$ steel specimens was beneficial for the coarsening of the MX and Z-phase precipitates. Despite the volume fraction and average particle size of the precipitates, it was positively correlated with the growth rate and $\mathrm{Nb}$ content during the $2 \mathrm{~h}$ heat treatment at $120{ }^{\circ} \mathrm{C}$. It was noticed that the volume fraction of the $\mathrm{Nb}-0.6$ steel specimen was close to that of the $\mathrm{Nb}-0.9$ steel specimen after the $6 \mathrm{~h}$ heat treatment. Moreover, the numerous fine precipitates formed with a size of approximately $0.4 \mu \mathrm{m}$ in the $\mathrm{Nb}-0.9$ steel specimen abruptly increased after $6 \mathrm{~h}$ of heat treatment, which caused the volume fraction of the precipitates to remain constant after $6 \mathrm{~h}$. Ghosh [31] and Zhou et al. [32] have demonstrated that increasing the isothermal temperature can increase the size and coarsening rate for carbonitrides. A high isothermal temperature increases the diffusion rate of atoms to reduce the number of carbonitride particles, increasing the distance among the growing particles. Even if the solute and matrix concentrations are gradually reduced, the driving force for the diffusion of interfacial solute atoms is reduced [33]. As the diffusion distance is directly proportional to time and the size variation of carbonitrides exhibits a parabolic relationship with aging time, the coarsening rate of MX and Z-phase precipitates is time-independent [32]. Therefore, the coarsening rate and volume fraction of the precipitates in the $\mathrm{Nb}-0.9$ steel specimen after $6 \mathrm{~h}$ of heat treatment were reduced compared with those of the precipitates in the $\mathrm{Nb}-0.6$ steel specimen.

\section{Conclusions}

In this study, hot-rolled plates of $22 \mathrm{Cr} 25 \mathrm{NiWCuCo}(\mathrm{Nb})$ heat-resistant steel were subjected to heat treatment at $1200{ }^{\circ} \mathrm{C}$ for $2 \mathrm{~h}$ to investigate the effect of $\mathrm{Nb}$ content on the precipitates formed in and thermal behavior of the plates and to understand the dominant phase constitution during treatment. The results reveal that the $\mathrm{Z}$ phase $(\mathrm{CrNb}(\mathrm{C}$, $\mathrm{N})$ ) and $\mathrm{MX}$ (including $\mathrm{Nb}(\mathrm{C}, \mathrm{N}),(\mathrm{Cr}, \mathrm{Fe})(\mathrm{C}, \mathrm{N})$, and $\mathrm{NbC}$ ) were the dominant precipitates in the $22 \mathrm{Cr} 25 \mathrm{NiWCuCo}(\mathrm{Nb})$ steel specimens. A high $\mathrm{Nb}$ content $(0.9 \mathrm{wt} \%)$ in $22 \mathrm{Cr} 25 \mathrm{NiWCuCo}(\mathrm{Nb})$ steel was determined to be beneficial for $\mathrm{NbC}$ formation as the $\mathrm{Nb}$ content reached $0.9 \mathrm{wt} \%$. After the heat treatment, the $\mathrm{Nb}$-free steel specimen exhibited a nonprecipitated microstructure that was dependent on the $\mathrm{Nb}$ content. This thus signifies that a high $\mathrm{Nb}$ content is beneficial for the precipitation of $\mathrm{NbC}$. Moreover, increasing the content of $\mathrm{Nb}$ is advantageous for suppressing grain growth at high temperatures because it promotes precipitate formation. The specimens' DSC profiles revealed that the melting point of the $22 \mathrm{Cr} 25 \mathrm{NiWCuCo}(\mathrm{Nb})$ steel samples decreased slightly as the $\mathrm{Nb}$ content increased. Extending the heat treatment duration to $6 \mathrm{~h}$ also promoted the coarsening and increased the volume fraction of the precipitates at $1200^{\circ} \mathrm{C}$. The $\mathrm{Z}$ phase replaced the MX to become the dominant precipitates at $1200^{\circ} \mathrm{C}$.

In steel manufacturing, homogenous treatment $\left(>1200^{\circ} \mathrm{C}\right)$ is an important process to obtain a uniform microstructure. The heterogeneous primary precipitates could influence the nucleation and growth of secondary precipitates during warm working. Moreover, understanding the $\mathrm{Nb}$ alloying addition and establishment of the Z-phase, MX, carbide precipitation mechanism at high temperature is beneficial to mechanical property relations. 
Therefore, the high-temperature deformation behavior of $2 \mathrm{Cr} 25 \mathrm{NiWCuCo}(\mathrm{Nb})$ steel is future research.

Author Contributions: Conceptualization, S.-M.Y., J.-L.W., Y.-T.P. and D.-Y.L.; data curation, S.M.Y. and J.-L.W.; formal analysis, S.-M.Y. and J.-L.W.; supervision, S.-M.Y.; funding acquisition, D.-Y.L.; investigation, S.-M.Y. and J.-L.W.; methodology, S.-M.Y., J.-L.W., Y.-T.P. and D.-Y.L.; project administration, D.-Y.L.; resources, Y.-T.P. and D.-Y.L. All authors have read and agreed to the published version of the manuscript.

Funding: This research was funded by the Ministry of Science and Technology, Taiwan (MOST 107-2218-E-390-005-MY3).

Institutional Review Board Statement: Not applicable.

Informed Consent Statement: Not applicable.

Data Availability Statement: Data sharing is not applicable to this article.

Acknowledgments: The authors thank the Ministry of Science and Technology, Taiwan, for funding this study in part under the contract MOST 107-2218-E-390-005-MY3.

Conflicts of Interest: The authors declare no conflict of interest.

\section{References}

1. Suo, J.; Peng, Z.; Yang, H.; Chai, G.; Yu, M. Formation of laves phase in Sanicro 25 austenitic steel during creep-rupture test at $700^{\circ} \mathrm{C}$. Metallogr. Microstruct. Anal. 2019, 8, 281-286. [CrossRef]

2. Maziasz, P.J. Development of creep-resistant and oxidation-resistant austenitic stainless steels for high temperature applications. JOM 2018, 70, 66-75. [CrossRef]

3. Zieliński, A.; Dudziak, T.P.; Golański, G.; Gazdowicz, J.; Kołodziej, A. Effects of long-term ageing at high temperatures on oxide scale development and evolution of austenitic steels microstructure. Steel Res. Int. 2020, 91, 1900595. [CrossRef]

4. Cempura, G.; Gil, A.; Agüero, A.; Gutiérrez, M.; Kruk, A.; Czyrska-Filemonowicz, A. Microstructural studies of the scale on Sanicro 25 after 25,000h of oxidation in steam using advanced electron microscopy techniques. Surf. Coat. Technol. 2019, 377, 124901. [CrossRef]

5. Golański, G.; Zieliński, A.; Sroka, M.; Słania, J. The effect of service on microstructure and mechanical properties of HR3C heat-resistant austenitic stainless steel. Materials 2020, 13, 1297. [CrossRef]

6. Zhou, R.; Zhu, L. Growth behavior and strengthening mechanism of $\mathrm{Cu}$-rich particles in sanicro 25 austenitic heat-resistant steel after aging at 973 K. Mater. Sci. Eng. 2020, A796, 139973. [CrossRef]

7. Sroka, M.; Zielinski, A.; Golański, G. Analysis of phase precipitation in Sanicro 25 Austenitic steel after ageing. Acta Phys. Pol. 2019, 135, 207-211. [CrossRef]

8. Zhou, Y.; Liu, Y.; Zhou, X.; Liu, C.; Yu, J.; Huang, Y.; Li, H.; Li, W. Precipitation and hot deformation behavior of austenitic heat-resistant steels: A review. J. Mater. Sci. Technol. 2017, 33, 1448-1456. [CrossRef]

9. Viswanathan, R.; Henry, J.F.; Tanzosh, J.; Stanko, G.; Shingledecker, J.; Vitalis, B.; Purgert, R.U.S. program on materials technology for ultra-supercritical coal power plants. J. Mater. Eng. Perform. 2005, 14, 281-292. [CrossRef]

10. Rutkowski, B.; Gil, A.; Agüero, A.; González, V.; Czyrska-Filemonowicz, A. Microstructure, chemical- and phase composition of Sanicro 25 austenitic steel after oxidation in steam at $700^{\circ} \mathrm{C}$. Oxid. Met. 2018, 89, 183-195. [CrossRef]

11. Zurek, J.; Yang, S.-M.; Lin, D.-Y.; Hüttel, T.; Singheiser, L.; Quadakkers, W.J. Microstructural stability and oxidation behavior of Sanicro 25 during long-term steam exposure in the temperature range $600-750^{\circ} \mathrm{C}$. Mater. Corros. 2015, 66, 315-327. [CrossRef]

12. Rana, R.; Bleck, W.; Singh, S.B.; Mohanty, O.N. Development of high strength interstitial free steel by copper precipitation hardening. Mater. Lett. 2007, 61, 2919-2922. [CrossRef]

13. He, J.; Sandström, R. Application of Fundamental Models for Creep Rupture Prediction of Sanicro $25(23 \mathrm{Cr} 25 \mathrm{NiWCoCu})$. Crystals 2019, 8, 638. [CrossRef]

14. Zieliński, A.; Dobrzański, J.; Ppuzyńska, H.; Sikora, R.; Dziuba-Kałuża, M.; Kania, Z. Evaluation of creep strength of heterogeneous welded joint in HR6W alloy and Sanicro 25 steel Arch. Metall. Mater. 2017, 62, 2057-2064. [CrossRef]

15. Calmunger, M.; Chai, G.; Eriksson, R.; Johansson, S.; Moverare, J.J. Characterization of Austenitic Stainless Steels Deformed at Elevated Temperature. Metall. Mater. Trans. 2017, A48, 4525-4538. [CrossRef]

16. Li, Y.; Liu, Y.; Liu, C.; Li, C.; Li, H. Mechanism for the formation of Z-phase in $25 \mathrm{Cr}-20 \mathrm{Ni}-\mathrm{Nb}-\mathrm{N}$ austenitic stainless steel. Mater. Lett. 2018, 233, 16-19. [CrossRef]

17. Zhou, R.; Zhu, L.; Liu, Y.; Lu, Z.; Chen, L. Precipitates and precipitation strengthening of Sanicro 25 welded joint base metal crept at 973 K. Steel Res. Int. 2017, 87, 1600414. [CrossRef]

18. Merda, A.; Sroka, M.; Klimaszewska, K.; Golański, G. Microstructure and mechanical properties of the Sanicro 25 steel after ageing. J. Achiev. Mater. Manuf. Eng. 2018, 91, 1-11. [CrossRef]

19. Sourmail, T. Precipitation in creep resistant austenitic stainless steel. J. Mater. Sci. Technol. 2001, 14, 1-14. [CrossRef] 
20. Chai, G.; Bostrom, M.; Olaison, M.; Forsberg, U. Creep and LCF behaviours of newly developed advanced heat resistant austenitic steels for A- USC. Procedia Eng. 2013, 55, 232-239. [CrossRef]

21. Peng, B.; Zhang, H.; Hong, J.; Gao, J.; Zhang, H.; Li, J.; Wang, Q. The evolution of precipitates of 22Cr-25Ni-Mo-Nb-N heat-resistant austenitic steel in long term creep. Mater. Sci. Eng. 2010, A527, 4424-4430. [CrossRef]

22. Wei, L.; Hao, W.; Cheng, Y.; Tan, S. Isothermal aging embrittlement in an Fe-22Cr-25Ni alloy. Mater. Sci. Eng. 2018, A737, 40-46. [CrossRef]

23. Terada, M.; Escriba, D.M.; Costa, I.; Materna-Morris, E.; Padliha, A.F. Investigation on the intergranular corrosion resistance of the AISI 316L(N) stainless steel after long time creep testing. Mater. Charact. 2008, 59, 663-668. [CrossRef]

24. Kaneko, K.; Futunaga, T.; Yamada, K.; Nakada, N.; Kikuchi, M.; Saghi, Z.; Barnad, J.S.; Midgley, P.A. Formation of $\mathrm{M}_{23} \mathrm{C}_{6}$-Type precipitates and chromium-depleted zone in austenite stainless steel. Scr. Mater. 2011, 65, 509-512. [CrossRef]

25. Raghavan, A.; Klein, C.F.; Marzinsky, C.N. Instabilities in stabilized austenitic stainless steels. Metall. Mater. Trans. 1992, $23 A, 2455-2467$.

26. Lula, R.A. New Developments in Stainless Steel Technology; American Society for Metals: Metals Park, OH, USA, 1985; ISBN 978-0-871-70205-0.

27. Vodárek, V. Morphology and orientation relationship of Z-phase in austenite. Scr. Metall. Mater. 1991, 25, 549-552. [CrossRef]

28. Heczko, M.; Esser, B.D.; Smith, T.M.; Beran, P.; Mazánová, V.; Kruml, T.; Polák, J.; Mills, M.J. On the origin of extraordinary cyclic strengthening of the austenitic stainless steel Sanicro 25 during fatigue at $700{ }^{\circ} \mathrm{C}$. J. Mater. Res. 2017, 32, 4342-4353. [CrossRef]

29. Ţălu, Ş. Micro and Nanoscale Characterization of Three Dimensional Surfaces: Basics and Applications; Napoca Star Publishing House: Cluj-Napoca, Romania, 2015.

30. Hillert, M. On the theory of normal and abnormal grain growth. Acta Metall. 1965, 13, 227-238. [CrossRef]

31. Ghosh, S. Kinetic study on the coarsening behaviour of equilibrium phases in $\mathrm{Nb}$ alloyed ferritic stainless steels at $700{ }^{\circ} \mathrm{C} . \mathrm{Mater}$. Chem. Phys. 2010, 124, 13-16.

32. Zhou, Y.-H.; Liu, C.-X.; Liu, Y.-C.; Guo, Q.-Y.; Li, H.-J. Coarsening behavior of MX carbonitrides in type 347H heat-resistant austenitic steel during thermal aging. Int. J. Miner. Metall. Mater. 2016, 23, 283-293. [CrossRef]

33. Xia, Z.X.; Zhang, C.; Yang, Z.G. Control of precipitation behavior in reduced activation steels by intermediate heat treatment. Mater. Sci. Eng. 2011, A528, 6764-6768. 